\title{
Characteristics of teacher knowledge produced by pre- service mathematics teachers: the case of open-ended problem-based learning
}

Jani Hannula

University of Helsinki, Finland

One major issue in mathematics teacher education regards the role of universitylevel mathematics in teacher knowledge. In the context of a design-based research project, an advanced mathematics teacher education course aimed at strengthening the connections between university-level mathematics and school mathematics was developed. In this paper, I present a case study, conducted within the education course, in which I analyse the characteristics of teacher knowledge produced by five small groups of pre-service teachers in an open-ended problembased learning task. The results indicate the problem-based learning approach has the potential for enhancing specialised content knowledge such as knowledge of different representations of and applications of mathematical concepts. The results also highlight the challenges in using this approach for enhancing horizon content knowledge such as knowledge about the relationships between mathematical concepts. The findings in this case study suggest that problem-based learning can be used to develop mathematics teacher education, although further research is needed to design instructional practices that enhance pre-service teachers' horizon content knowledge.

\author{
Keywords \\ problem-based, \\ learning, \\ design-based research, \\ mathematical knowledge for \\ teaching, \\ specialised content \\ knowledge, \\ horizon content knowledge, \\ pre-service teachers, \\ teacher knowledge \\ Correspondence \\ jani.hannula@helsinki.fi \\ DOI \\ https://doi.org/10.31129/ \\ LUMAT.7.3.391
}

\section{Introduction}

Finnish mathematics teacher education has traditionally put a strong emphasis on subject matter knowledge that is based on courses in advanced mathematics. This tradition is common also in several other countries such as Israel and France (Tatto, Lerman, \& Novotna, 2009). The assumption underlying this tradition is that strong subject-matter knowledge rooted in academic mathematics improves teachers' classroom instruction (Even, 2011). However, mathematician Felix Klein (1908/1932) pointed out already more than a century ago that maths teacher education suffers from a 'double discontinuity'. Firstly, when entering university, prospective teachers confront mathematics that is different from what they studied at school. Secondly, after finishing their degrees, novice teachers end up teaching school maths 'traditionally' without any clear connection to the advanced maths they studied at university (Klein, 1908/1932, p. 1).

Nowadays, a large body of maths education research describing different aspects of the double discontinuity exists: the research literature has addressed issues related 
to secondary-tertiary transition (e.g. Clark \& Lovric, 2009), as well as issues related to the development of teacher knowledge (e.g. Moreira \& David, 2008). However, the question of utilising knowledge of advanced maths in enhancing mathematical knowledge for teaching has only recently started to gain more attention in the literature, and this research area is still scattered (e.g. Even, 2011; Mosvold \& Fauskanger, 2014; Paolucci, 2015; Wasserman, 2016; Zazkis \& Leikin, 2010). In particular, there is a lack of research exploring the development of teacher knowledge in course settings aimed at strengthening the connections between advanced maths and school maths (e.g. Wasserman, 2016).

In this paper, I present a case study conducted within a larger design-based research project. The larger project was initiated in order to address the 'second half' of Klein's discontinuity: the aim was to design a maths teacher education course that helps pre-service teachers to connect advanced maths to school maths. The case study presented in this paper focusses on the characteristics of teacher knowledge produced by pre-service teachers in problem-based learning (PBL) task assigned in this course. The purpose of the case study is to add insight into the potentials and challenges presented by the utilisation of open-ended PBL approaches in maths teacher education.

\section{Theoretical framework}

Theories used and developed in design-based research can be divided into grand theories, orienting frameworks, frameworks for action and domain-specific instructional theories (DiSessa \& Cobb, 2004). In the current case study, I use theories from higher education research literature as frameworks for action. Thus, they are utilised in the instructional design of the design artefact. Additionally, domainspecific instructional theories of teacher knowledge are used for the data analysis and problem analysis.

\subsection{Frameworks for action}

Finnish universities have a long tradition of research-based teacher education (Toom et al., 2010). This research-based approach applies to course contents as well as to teaching methods. On the one hand, course content should be informed by the research literature on the discipline at hand. On the other hand, the teaching and learning methods should be informed by the literature on higher education research 
(Toom et al., 2010). During recent decades, social constructivism has been a dominant starting point for instructional design.

In higher education, one widely adopted framework based on social constructivism is the model of constructive alignment (Biggs \& Tang, 2011). The idea of constructive alignment is that the intended learning outcomes, and the teaching and learning methods, as well as the assessment, should be carefully designed and aligned with each other. Additionally, teaching and learning methods should be aligned with the theory of social constructivism. Therefore, university students should work actively in a social environment in order to build new knowledge. This kind of approach is stated to raise student engagement and achievement (Figure 1).

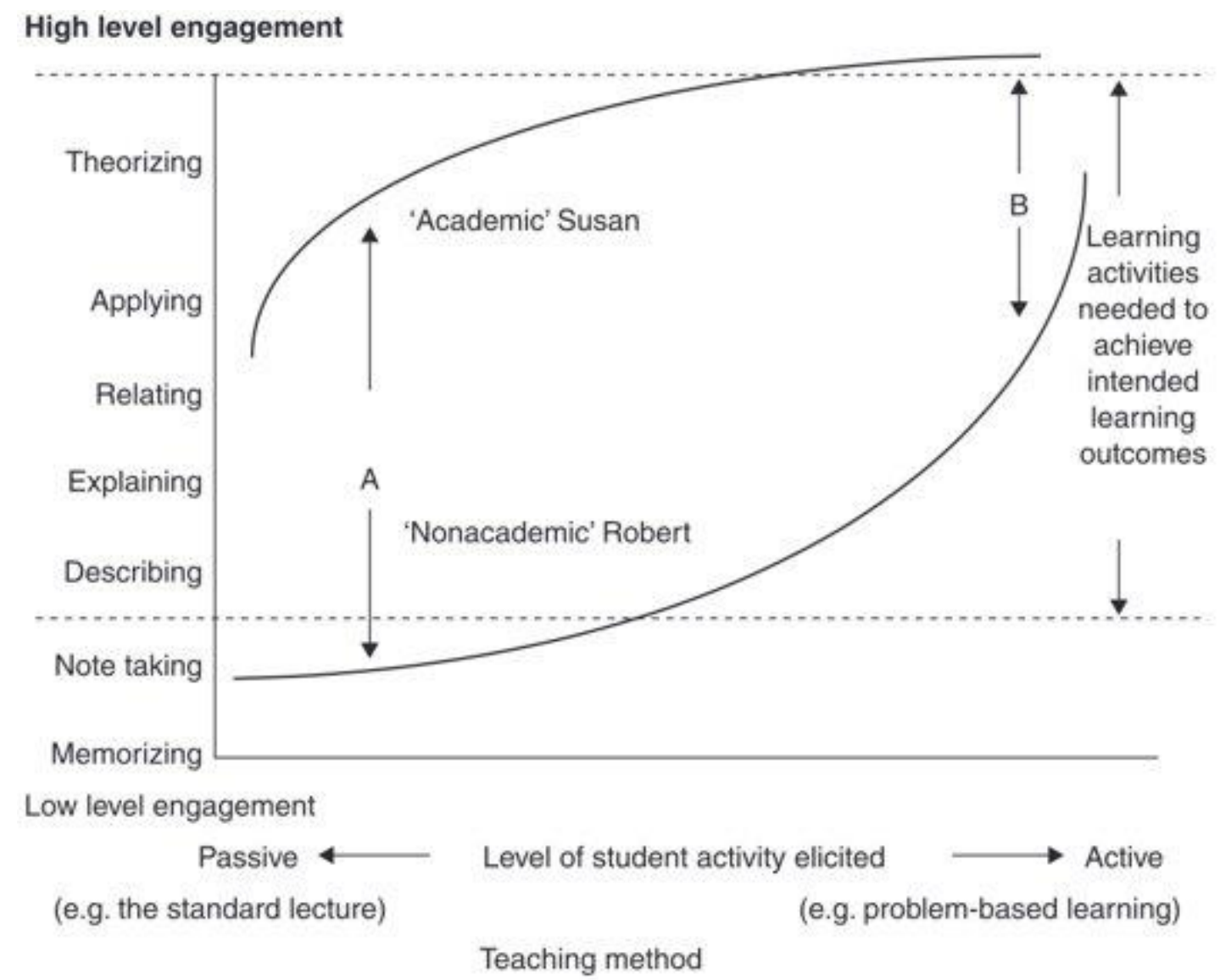

Figure 1. The relationship between teaching method and student engagement (Biggs \& Tang, 2011).

With the constructive alignment model, several different teaching and learning methods can be used. In the case study reported in this paper, PBL is adopted. The core idea of PBL is that learning is bound to real-world problems and social interaction. Therefore, PBL aims to enhance not only students' subject matter 
knowledge but also generic skills such as problem-solving and collaboration (HmeloSilver, 2004).

Although there are several ways to implement PBL, it always starts with a realworld problem (a case) analysed by a group of students, and it includes both collaborative and individual work. The seven-step model proposed by Schmidt (1983) (Table 1) is a widely used description of PBL and is also the model adopted in the case study.

Table 1. The steps involved in problem-based learning (Schmidt, 1983).

\begin{tabular}{l|l}
\hline Step & Description \\
\hline Step 1 & Clarify terms and concepts not readily comprehensible. \\
Step 2 & Define the problem. \\
Step 3 & Analyse the problem. \\
Step 4 & Draw a systematic inventory of the explanations inferred from step 3. \\
Step 5 & Formulate learning objectives. \\
Step 6 & Collect additional information outside the group. \\
Step 7 & Synthesize and test the newly acquired information.
\end{tabular}

The PBL process begins with a classroom session in which a case is presented to a group(s) of students. The first five steps of Schmidt's model take place in this classroom session. During these steps, students carefully analyse the problem and their previous knowledge and, finally, formulate the learning objectives for the process. That is the group analyses what kind of new knowledge they should learn to solve the problem. It is worth noticing that the cases are typically open-ended and 'illstructured' (Hmelo-Silver, 2004). Therefore, learning objectives formulated by the groups are typically diverse. After formulating the learning objectives, all the individual students in the group search for literature and theories related to these objectives. The final step of the process is that the group synthesises the new knowledge found during the process.

\subsection{Domain-specific instructional theories}

Research on teacher knowledge has been greatly influenced by the seminal work of Shulman (1987), whose distinction between subject matter knowledge, pedagogical knowledge and pedagogical content knowledge is still an underlying idea in most of the existing research on the topic. For Shulman, subject matter knowledge refers to 'pure' knowledge of the discipline or the subject (such as mathematics). Pedagogical 
knowledge refers to general knowledge about the many aspects of pedagogy, such as learning theories. Pedagogical content knowledge, in turn, refers to a 'special amalgam' of content and pedagogy, meaning the special issues related to the teaching and learning of a specific subject.

Shulman's distinction has been elaborated, especially in the mathematical knowledge for teaching (MKT) model (Ball, Thames \& Phelps, 2008). In this model, subject matter knowledge (SMK) is divided into common content knowledge (CCK), specialised content knowledge (SCK) and horizon content knowledge (HCK). Similarly, pedagogical content knowledge is divided into the knowledge of content and students (KCS), knowledge of content and teaching (KCT) and knowledge of content and curriculum (KCC). This model aims to give a detailed description of the mathematical knowledge needed in teaching professions (Figure 2).

Subject matter knowledge (SMK)

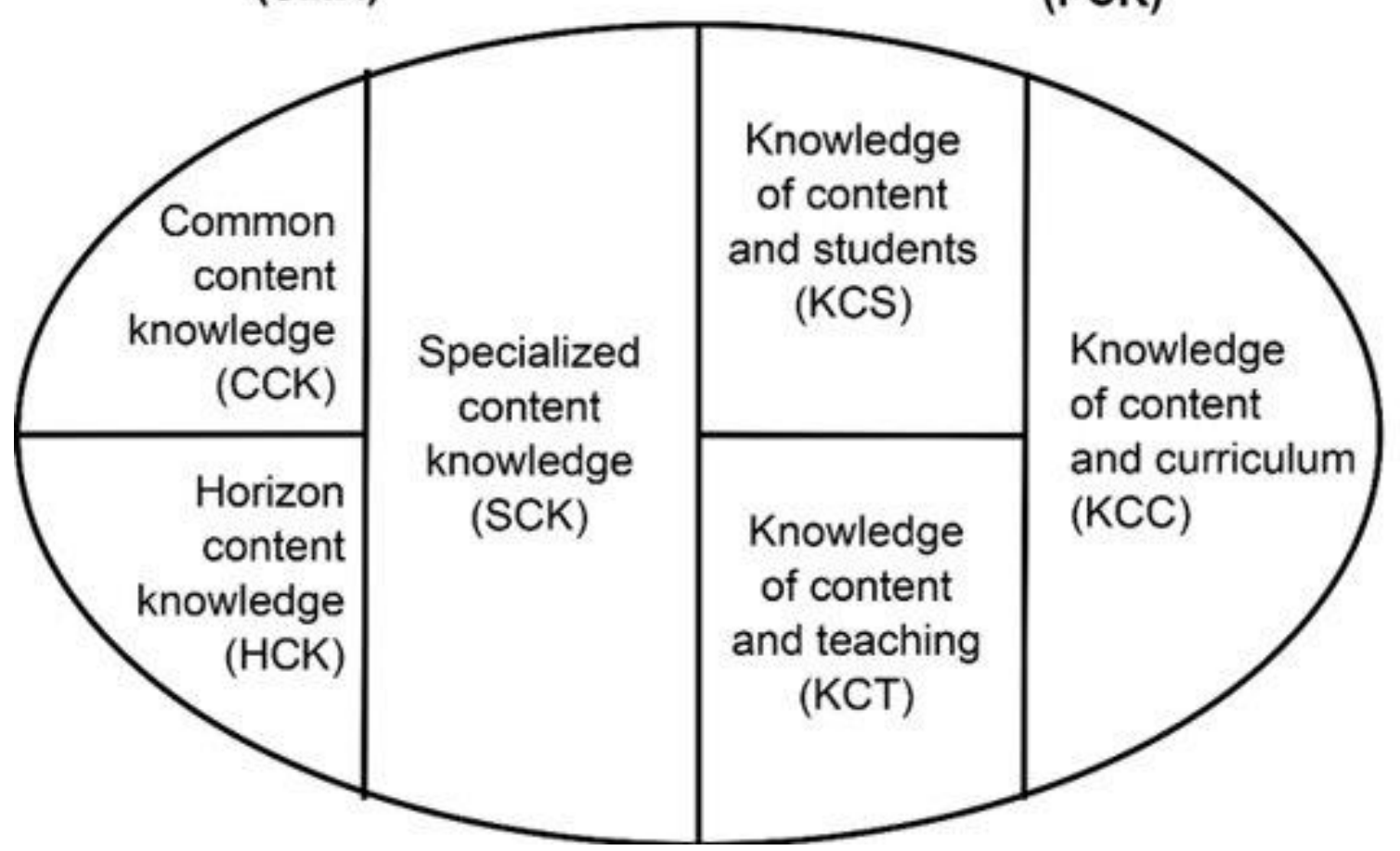

Figure 2. The mathematical knowledge for teaching model (Ball et al., 2008).

Pedagogical content knowledge

(PCK) . 
specific for teachers, such as modifying mathematical tasks and being familiar with different representations of the content. These definitions, however, are somewhat problematic as the line between 'common' and 'specialised' seems to be contextual (Carrillo, Climent, Contreras \& Muñoz-Catalán, 2013). Lastly, HCK is defined as 'awareness how mathematical topics are related throughout mathematics included in the curriculum' (Ball et al., 2008, p. 403).

With respect to PCK, Ball et al. (2008) state that KCS contains content-specific knowledge of students. This includes, for instance, knowledge of students' typical (mis)conceptions. As another domain Ball et al. delineate is KCT, which is understood as content-specific knowledge regarding classroom orchestration. This kind of knowledge includes, for instance, the ability to sequence lessons 'logically'. Lastly, the domain of KCC is defined as knowledge of curriculum and teaching material such as textbooks (Ball et al., 2008; Koponen, Asikainen, Viholainen \& Hirvonen, 2016).

The domains of SCK and HCK are significant in developing maths teacher education. Firstly, these areas are reported as underrepresented in maths teacher education by Finnish in-service teachers and by teacher educators (Koponen et al., 2016). Secondly, the domains are closely related to the second half of Klein's double discontinuity, as they relate to 'specialising' the common content knowledge for teaching purposes and connecting broader disciplinary territory to the school subject and the teaching of it (Jakobsen, Thames \& Ribeiro, 2013).

\section{Literature review}

The core concepts underlying the case study are specialised content knowledge and horizon content knowledge. In the following subsections, I outline prior research related to these concepts from the perspective of curricular and task design as well as practitioners' views and knowledge.

\subsection{Specialised content knowledge: Curricular and task design}

Recently, new approaches have been proposed to strengthen pre-service teachers' mathematical knowledge for teaching. These approaches typically include tasks that take into account both SMK and PCK (Hoover, Mosvold, Ball \& Lai, 2016) and aim to break the boundaries between mathematical content taught in mathematics departments and mathematics pedagogy taught in education departments (e.g. Goos \& Bennison, 2018). So far, research on such development has mainly focussed on 
strengthening elementary and middle school teachers' specialised content knowledge.

Many researchers have proposed task designs that combine the development of SMK and analysis of teaching and/or learning. For instance, Jakobsen, Ribeiro and Mellone (2014) used professional learning tasks in order to reveal prospective primary teachers' mathematical knowledge for teaching. In these tasks, the participants solve mathematical problems and analyse students' answers to the same problem. The results of this study showed that prospective primary teachers' insufficient common content knowledge is problematic in terms of developing SCK. Silver, Clark, Ghousseini, Charalambous and Sealy (2007) used similar professional learning tasks for middle school teachers. They suggest that such an approach helps to build or strengthen connections among related mathematical ideas-and to consider these ideas in relation to how students think about the ideas and to a range of pedagogical actions and decisions that affect students' opportunities to learn' (p. 261). Koellner et al. (2007), in turn, present a teaching model called 'problem-solving cycle'. This model was designed for middle school teachers, and it includes solving mathematical problems, lesson planning and analysing the videotaped lessons. As one of their key findings, they argue that the development of specialised content knowledge is evident in the ways the participants compared, reasoned about and made connections between the various solution strategies.

Very few studies concern developmental projects aimed at enhancing secondary teachers' mathematical knowledge for teaching. Typically, mathematics courses given to pre-service secondary maths teachers are based on advanced mathematics and, consequently, may remain unconnected to mathematics taught at school (Moreira \& David, 2008). Therefore, some authors (e.g. Papick, 2011; Wasserman, 2016) have proposed tasks for secondary teachers that aim to make advanced mathematical content relevant for developing teacher knowledge. Such tasks aim to combine SMK and authentic classroom situations and to expose the connections between abstract concepts (such as associativity) and school mathematics content (such as mental arithmetic). The results of a study by Wright, Murray and Basu (2016) suggest that such designs can enhance teachers' knowledge of concepts such as inverse elements. However, so far, very little is known of the effects of such course designs and more research is needed to develop such instructional practices (e.g. Wasserman, 2016; Wright et al., 2016). 


\subsection{Horizon content knowledge: teachers' views and knowledge}

During the last decade, the construct of horizon content knowledge has been elaborated upon in response to criticism that it is conceptually problematic (Ball et al., 2008; Jakobsen et al., 2013). HCK is typically associated with knowledge of advanced mathematics, but advanced maths is considered necessary yet not sufficient on its own for the development of HCK (Zazkis \& Leikin, 2010). Jakobsen et al. (2013, p. 3128) redefine HCK as 'an orientation to and familiarity with the discipline (or disciplines) that contribute to the teaching of the school subject at hand, providing teachers with a sense for how the content being taught is situated in and connected to the broader disciplinary territory'. In this sense, HCK also includes 'explicit knowledge on ways of and tools for knowledge in the discipline that enables teachers to understand and make judgements of students' statements and reasoning' (p. 3128).

A large proportion of research related to HCK has concentrated on pre-service and in-service teachers' views. In general, both pre-service and in-service teachers have perceived university-level mathematics and school maths as somewhat distinct areas (Hannula, 2018a; Koponen et al., 2016; Mosvold \& Fauskanger, 2014; Paolucci, 2015). Additionally, some studies (Mosvold \& Fauskanger, 2014; Wasserman, Weber, Villanueva \& Mejia-Ramos, 2018) suggest that in-service teachers emphasise the mathematical content at the level they are teaching, disregarding the broader mathematical context. Some pre-service teachers, however, state that advanced mathematics is important for teacher knowledge (Hannula, 2018a; Zazkis \& Leikin, 2010). These pre-service teachers, however, do not typically give concrete examples of how advanced mathematical knowledge helps them in their future work. Nevertheless, there is some evidence that pre-service and in-service teachers perceive advanced maths as useful in terms of some specific content such as the history of mathematics and game theory (Even, 2011; Paolucci, 2015).

Some studies examining teachers' knowledge have focussed on the connections between university mathematics and school maths. These studies highlight that exposure to university mathematics does not necessarily change conceptions based on school mathematics and that connecting these domains coherently is difficult for pre-service teachers. For instance, pre-service teachers very often perceive an equation as a process of solving a variable and more rarely perceive it as a statement about the equality of two numbers (Tossavainen, Attorps \& Väisänen, 2011). More generally, combining informal reasoning based on graphs and physical 
interpretations with formal reasoning based on definitions is difficult for pre-service teachers (Viholainen, 2008). Many pre-service teachers explain concepts and properties such as vectors and their distributive property informally using graphs and examples (Hannula, 2018a). These conceptions can become problematic in more complex situations as, for instance, all properties of the sine function cannot be explained using 'triangle trigonometry' (Chin, 2013). As the formal definitions often remain unconnected from informal conceptions, many pre-service teachers hold several misconceptions regarding concepts such as irrational numbers (Sirotic \& Zazkis, 2007).

\section{Context}

\subsection{The larger research project}

A design-based research project was initiated in 2014 in order to design an advanced course for pre-service mathematics teachers aiming to address the second half of Klein's discontinuity. Following the principles presented by Edelson (2002), an iterative process was composed of an initial problem analysis and case studies of three-course designs (Figure 3 ).

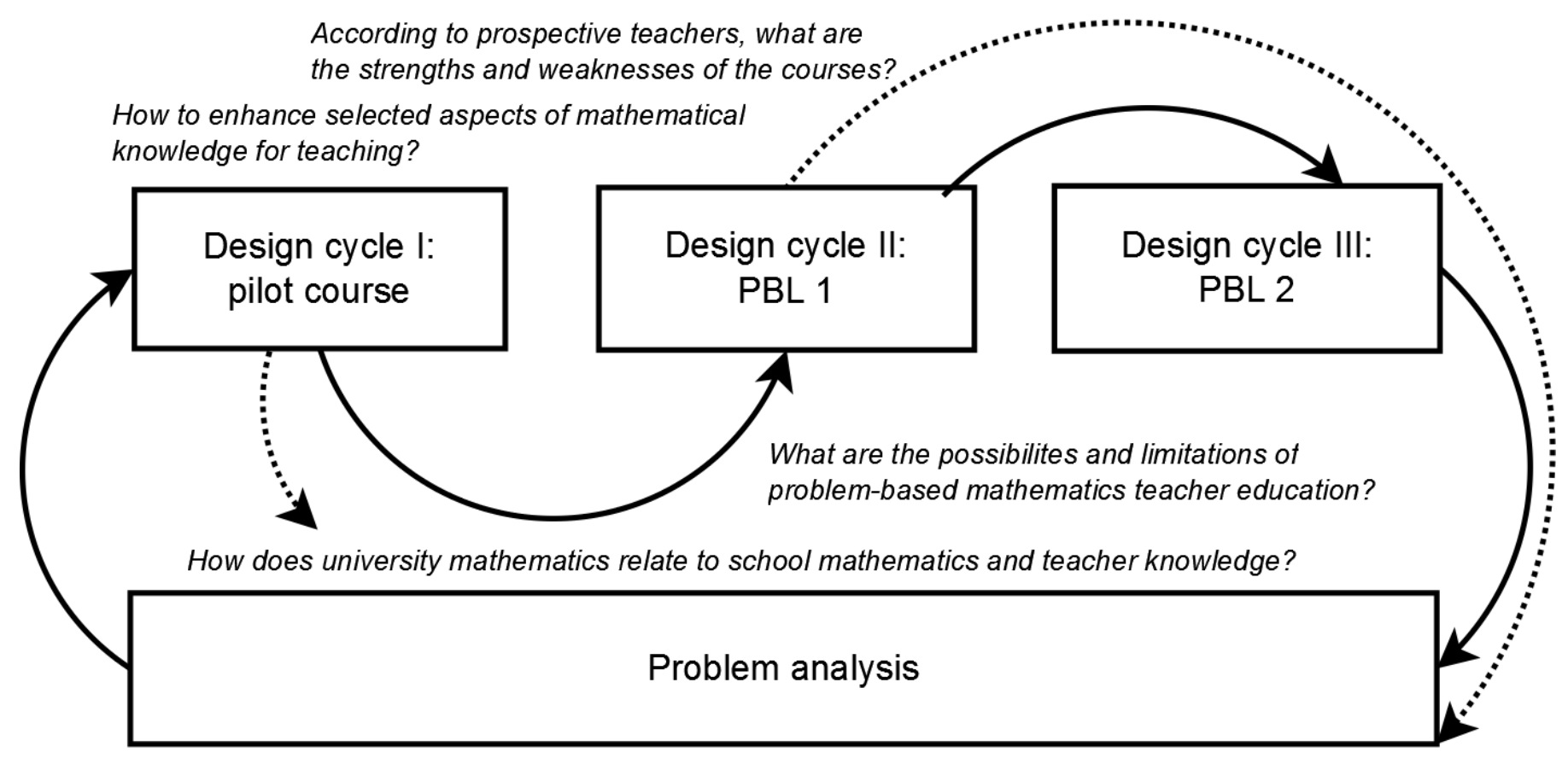

Figure 3. The design process. 
Results of the initial empirical problem analysis have been published in Hannula (2018a). Additionally, some results from design cycles I and II have been published in Hannula (2017) and Hannula (2018b), respectively.

\subsection{The course design of cycle III}

The case study was conducted in the course designed for cycle III. The learning objectives of this course emphasised horizon content knowledge and specialised content knowledge. This seven-week course (3 ECTS credits) had contents related to real analysis, vectors, number systems and logic. The course was taught by the author of this paper.

The course included two PBL tasks as well as lectures and case-based learning. This case study focusses on one of the PBL tasks. This task was implemented following the seven-step model described in section 2.1.

\section{Aims and research question}

During the first two cycles of the research project, it was notable that the pre-service teachers mainly discussed PCK and SCK in their learning tasks. More accurately, they concentrated, for instance, on forming knowledge related to students' misconceptions or different representations of mathematical content, laying less stress on HCK and certain areas of SCK such as modifying tasks. After the first two cycles, the tasks of the course were refined. During cycle III, the aim was to analyse more closely the characteristics of teacher knowledge produced in one such task. Therefore, in this paper, the following research question is examined:

- What kind of mathematical knowledge for teaching does open-ended PBL provoke in a setting where especially specialised content knowledge and horizon content knowledge are intended to be enhanced?

In relation to prior research literature, the case study has two aims. First, to add to prior literature on SCK and task design by analysing open-ended PBL in the context of pre-service secondary teachers. Second, to give insight into how this task design might enhance the development of HCK, the category that is - in the light of existing literature - problematic from several perspectives. 


\section{Methods}

\subsection{Data gathering and study design}

The current study focusses on one of the course's PBL tasks. This task was related to vectors and linear algebra. The case presented to pre-service teachers was a hypothetical scenario, formulated by the course teacher, in which a novice teacher ponders the connections between a secondary school course on vectors and a university-level linear algebra course. The original case is written in Finnish as well as an English translation is given in Appendix I.

The pre-service teachers formed six small groups (5-6 participants) in which they worked on the PBL tasks. All of the groups prepared a poster presentation of their work. These poster presentations were then presented to other groups. A more detailed description of the groups' working schedule is given in Appendix II.

The poster presentations of the groups were used as the data in this study. Only the work of five of these groups was analysed. The one presentation left outside the analysis was primarily a comparison of textbooks. That is, their presentation text consisted almost entirely of direct quotations from textbooks and was therefore not considered appropriate for the analysis.

The current study is a case study conducted within a larger project. The course itself is seen as the case. Within the case, five small groups are examined as lowerlevel units of analysis. Thus, using the terminology of Yin (1994), an embedded case study was conducted (Figure 4).

The unit of analysis:

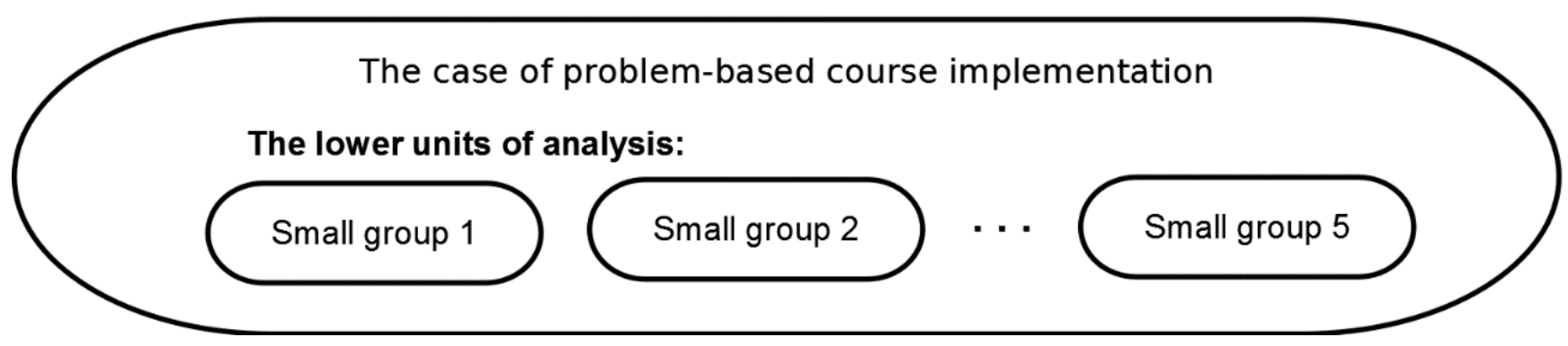

Figure 4. The case study design. 


\subsection{Participants}

The course had 33 participants whom all gave permission to use their work for the research. Of these participants, 29 had mathematics as their major subject, and two had mathematics as a minor subject and were majoring in education. Additionally, two students already had a Master's degree in another subject and were studying intermediate mathematics to qualify as mathematics teachers as well.

\subsection{Data analysis}

Content analysis (Elo \& Kyngäs, 2008) was used as the basic method to examine the data. More accurately, a combination of deductive (directed) and inductive (conventional) content analysis was used. This process was based on the deductiveinductive path model presented by Elo \& Kyngäs (2008, p. 110). Two researchers conducted the analysis to enhance the trustworthiness of the process.

First, the units of analysis were determined. A unit of analysis was defined as a written text, a picture or a combination of the two that constitutes one separate idea or statement. The units were initially formed by one researcher, and then the two researchers discussed the outcome and refined the units together. In the second step, the two researchers independently placed each unit of analysis into the categories used in the MKT model.

In the third step, the independent categorisations were cross-tabulated, and Cohen's kappa (Cohen, 1960) was calculated to evaluate the researchers' level of agreement. The kappa value was 0.45 , which according to the scale proposed by Landis and Koch (1977) shows that the agreement level was moderate (Table 2).

Table 2. The Kappa Values and Level of Agreement (Landis \& Koch, 1977).

\begin{tabular}{ll}
\hline Kappa value & Level of agreement \\
\hline$<0.00$ & Poor \\
$0.00-0.20$ & Slight \\
$0.21-0.40$ & Fair \\
$0.41-0.60$ & Moderate \\
$0.61-0.80$ & Substantial \\
$0.81-1.00$ & Almost perfect \\
\hline
\end{tabular}

Looking at the cross-tabulation of the two classifications, it is evident that $87 \%$ of the disagreement is about drawing the line between the following boundaries: CCK 
vs. SCK, HCK vs. SCK and KCS vs. SCK (Table 3). These three boundary problems are exactly the same that have been pointed out in the literature (e.g. Carrillo et al., 2013).

Table 3. The cross-tabulation of the two researchers' classifications.

\begin{tabular}{|c|c|c|c|c|c|c|c|c|}
\hline & & \multicolumn{7}{|c|}{ Researcher 2} \\
\hline & & CCK & SCK & HCK & KCS & KCT & KCC & $\Sigma$ \\
\hline \multirow[t]{7}{*}{ Researcher 1} & CCK & 12 & 14 & 1 & 0 & 0 & 0 & 27 \\
\hline & SCK & 4 & 41 & 0 & 10 & 0 & 0 & 55 \\
\hline & HCK & 2 & 6 & 2 & 0 & 0 & 0 & 10 \\
\hline & KCS & 0 & 0 & 0 & 12 & 0 & 0 & 12 \\
\hline & KCT & 0 & 0 & 0 & 1 & 0 & 0 & 1 \\
\hline & KCC & 0 & 2 & 0 & 0 & 0 & 4 & 6 \\
\hline & $\Sigma$ & 18 & 63 & 3 & 23 & 0 & 4 & 111 \\
\hline
\end{tabular}

As the fourth step, contested unit categorisations were discussed by the researchers case by case, and the researchers' justifications for the categorisations were compared. The majority of these units were finally coded as SCK, as the reviewed research literature typically supported this interpretation (Table 4). In the end, a full agreement was achieved. As the last step, the second researcher formed the subcategories. Whenever possible, the subcategories were formed based on the categories suggested in the literature (e.g. Ball et al., 2008; Koponen et al., 2016). For those units of analysis that could not be placed in any of these subcategories, subcategories were formed inductively.

Table 4. An example of the data analysis process.

\begin{tabular}{|c|c|c|c|}
\hline Example & $\begin{array}{l}\text { Proposed } \\
\text { categories }\end{array}$ & $\begin{array}{l}\text { Decided category (and } \\
\text { justification) }\end{array}$ & Sub-category \\
\hline $\begin{array}{l}\text { "Using the decomposition } \\
\text { representation makes it clear } \\
\text { with respect to which basis is } \\
\text { the vector given." }\end{array}$ & SCK and CCK & $\begin{array}{l}\text { SCK (recognising what is involved } \\
\text { in using a particular } \\
\text { representation (Ball et al., 2008)) }\end{array}$ & $\begin{array}{l}\text { Characteristics of a } \\
\text { representation }\end{array}$ \\
\hline
\end{tabular}




\section{Results}

I present the results of the analysis in subsections for each lower unit of analysis (i.e. by presentation group).

\subsection{Group 1}

Group 1 focussed on the definitions and properties of mathematical objects as well as on secondary school curricula and textbooks (Table 5).

Table 5. The categorisation of the teacher knowledge produced by Group 1

\begin{tabular}{|c|c|c|c|}
\hline $\begin{array}{l}\text { Common content knowledge } \\
\text { (8) }\end{array}$ & $\begin{array}{l}\text { Specialised content } \\
\text { knowledge (2) }\end{array}$ & $\begin{array}{l}\text { Horizon content } \\
\text { knowledge (1) }\end{array}$ & $\begin{array}{l}\text { Knowledge of } \\
\text { content and } \\
\text { curriculum (4) }\end{array}$ \\
\hline $\begin{array}{l}\text { A formal definition (4), } \\
\text { properties of a mathematical } \\
\text { concept ( } 2 \text { ), a descriptive } \\
\text { definition (1), an example of a } \\
\text { concept (1) }\end{array}$ & $\begin{array}{l}\text { Characteristics of } \\
\text { representation (1), } \\
\text { applications (1) }\end{array}$ & $\begin{array}{l}\text { Relationship of the } \\
\text { concepts (1) }\end{array}$ & $\begin{array}{l}\text { Upper secondary } \\
\text { school curriculum (2), } \\
\text { the content of a } \\
\text { textbook (2) }\end{array}$ \\
\hline
\end{tabular}

The common content knowledge discussed in this group's work was focussed on the core definitions and properties related to vectors. These definitions and properties were discussed mostly in terms of the definitions given in university-level courses:

"Set $\mathrm{V}$ is a vector space, if it satisfies the following conditions: (...)"

In some parts, the group also connected common content knowledge to knowledge of content and curriculum:

"For instance, R2 and R3 are vector spaces and in secondary school one typically concentrates on them."

Regarding knowledge of content and curriculum, Group 1 focussed on the upper secondary school curriculum. The group also discussed the content of the curriculum in relation to textbooks:

“(...) the calculation rules of vectors, unit vector, null vector and inverse vector are presented (...)" 
In summary, Group 1 seemed to make an overview of the core mathematical concepts related to the theme 'vectors' and connected this knowledge to school maths curricula. However, only occasional observations from the perspective of SCK and HCK were made.

\subsection{Group 2}

Group 2 focussed on subject matter knowledge from various perspectives (Table 6).

Table 6. The categorisation of the teacher knowledge produced by Group 2.

\begin{tabular}{lll}
\hline Common content knowledge (3) & $\begin{array}{l}\text { Specialised content } \\
\text { knowledge (6) }\end{array}$ & $\begin{array}{l}\text { Horizon content knowledge } \\
\text { (2) }\end{array}$ \\
\hline $\begin{array}{l}\text { A descriptive definition (1), properties } \\
\text { of a mathematical concept (1), }\end{array}$ & $\begin{array}{l}\text { Applications (2), an example } \\
\text { (3), linking a representation }\end{array}$ & $\begin{array}{l}\text { Relationship of the concepts } \\
\text { (2) } \\
\text { alternative definitions (1) }\end{array}$ \\
\hline
\end{tabular}

The group discussed the mathematical content related to dot product both from the perspective of common content knowledge and horizon content knowledge. As an example of common content knowledge, the group presented alternative definitions of the dot product (Figure 5).

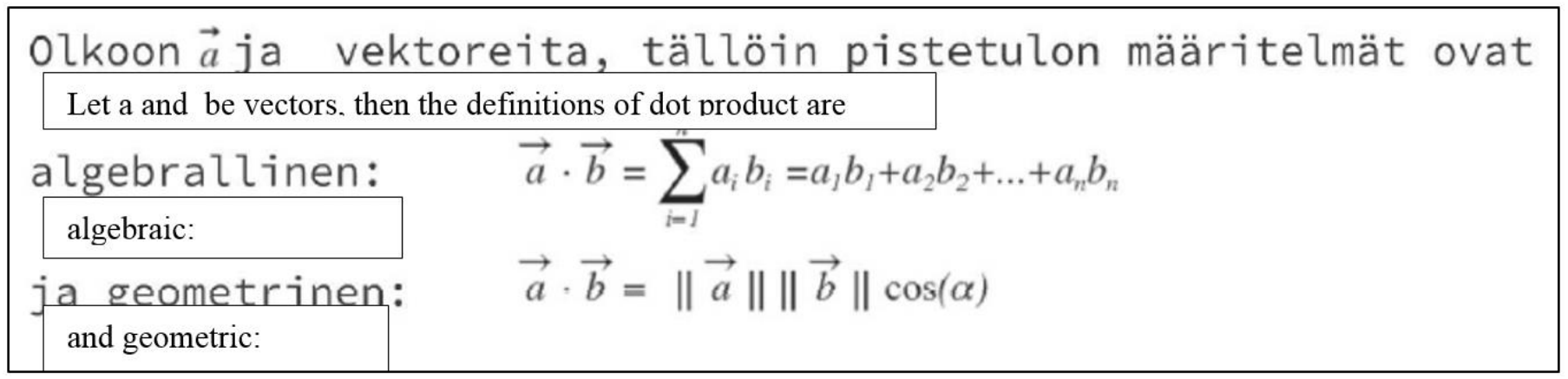

Figure 5. The alternative definitions of dot product presented by Group 2.

Regarding horizon content knowledge, the group explicated the relationship between the concepts:

"Dot product or scalar product is a real space's special case of inner product."

With respect to specialised content knowledge, the group presented applications, examples and a visual representation of dot product: 
“(...) however, if force and transition are not parallel, dot product is used to calculate the work (...)"

In summary, the group discussed subject matter knowledge comprehensively, taking into account the viewpoints related to common content knowledge, to specialised content knowledge and to horizon content knowledge.

\subsection{Group 3}

Group 3 focussed heavily on knowledge of content and students. Additionally, the group presented some observations related to the different representations (Table 7 ).

Table 7. The categorisation of the teacher knowledge produced by Group 3.

\begin{tabular}{lll}
\hline Specialised content knowledge (2) & $\begin{array}{l}\text { Knowledge of content and } \\
\text { students (11) }\end{array}$ & $\begin{array}{l}\text { Knowledge of content and } \\
\text { teaching (1) }\end{array}$ \\
\hline Linking a representation to an & $\begin{array}{l}\text { Students' misconceptions (7), } \\
\text { difficult content for students } \\
\text { underlying idea (2) }\end{array}$ & $\begin{array}{l}\text { Choosing a representation in } \\
\text { (2), students' conceptions (1), }\end{array}$ \\
& students' capability (1) & \\
\hline
\end{tabular}

The knowledge of content and students presented by this group was focussed on students' (mis)conceptions as well as on students' difficulties and capability in terms of mathematical tasks:

"Students think that dot product gives a vector".

"The students performed better in adding vectors algebraically than in adding them graphically".

In some parts, the group also discussed the representations of vectors in relation to the underlying ideas and choosing the representation in a teaching situation (Figure 6). 


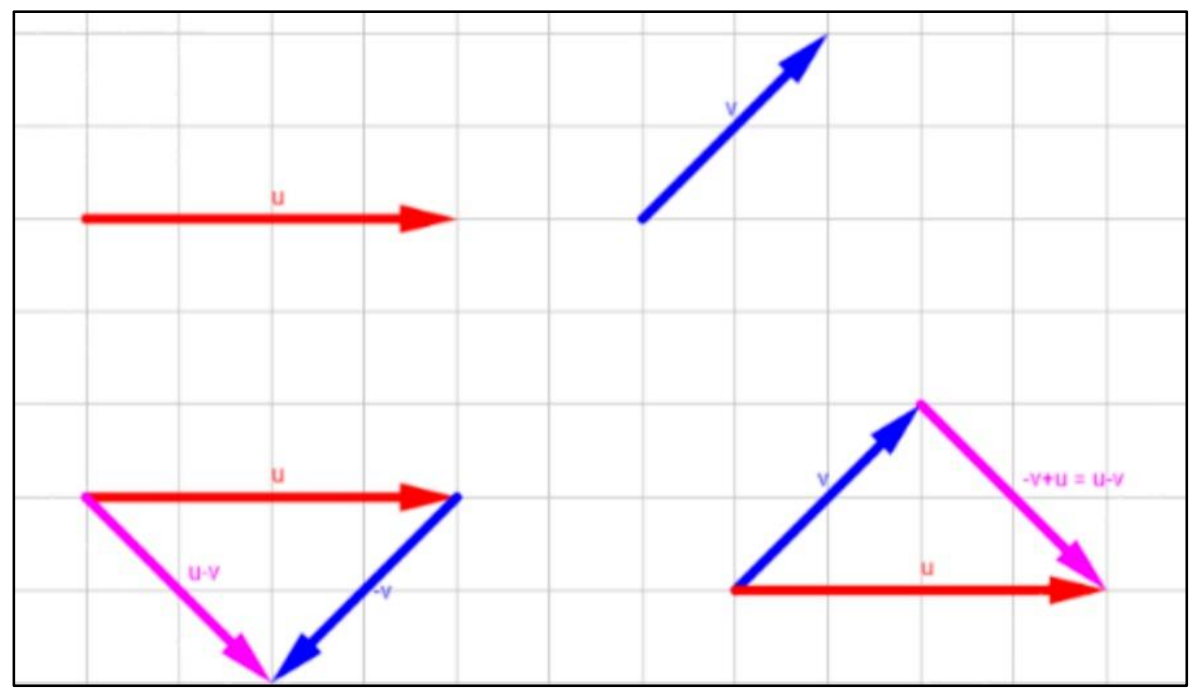

Figure 6. A representation of an inverse vector, the addition of vectors and the commutativity property presented by Group 3.

In summary, Group 3 had a viewpoint on students' conceptions of vectors and operations such as addition and dot product. Some observations of representations were also made, but the overall focus was on summarising students' knowledge and beliefs about vectors.

\subsection{Group 4}

The most dominant category in the work of Group 4 was specialised content knowledge. This knowledge was focussed entirely on analysing different representations (Table 8).

Table 8. The categorisation of the teacher knowledge produced by Group 4

\begin{tabular}{llll}
\hline $\begin{array}{l}\text { Common content } \\
\text { knowledge (6) }\end{array}$ & $\begin{array}{l}\text { Specialised content } \\
\text { knowledge (25) }\end{array}$ & $\begin{array}{l}\text { Knowledge of } \\
\text { content and students }\end{array}$ & $\begin{array}{l}\text { Knowledge of content } \\
\text { and curriculum (1) }\end{array}$
\end{tabular}

(2)

\begin{tabular}{llll}
\hline $\begin{array}{l}\text { A formal definition (3), } \\
\text { mathematical terms }\end{array}$ & $\begin{array}{l}\text { Characteristics of a } \\
\text { representation (20), }\end{array}$ & $\begin{array}{l}\text { Difficult content for } \\
\text { students (2) }\end{array}$ & $\begin{array}{l}\text { Upper secondary school } \\
\text { curriculum (1) }\end{array}$ \\
$\begin{array}{l}\text { (1), a descriptive } \\
\text { definition (1), an }\end{array}$ & $\begin{array}{l}\text { to an underlying idea or } \\
\text { example of a concept }\end{array}$ & $\begin{array}{l} \\
\text { other representations (5) }\end{array}$ & \\
(1) & & \\
\hline
\end{tabular}

To support their analysis of different representations of vectors, the group presented a fair amount of common content knowledge: 
[The decomposition of a vector (title)] "A vector is presented using certain unit vectors".

From the perspective of specialised content knowledge, the group repeatedly analysed what is involved using a certain representation:

"Using the decomposition representation makes it clear with respect to which basis is the vector given".

To some extent, this group also connected the representations to underlying ideas or other representations such as the idea of representing the vectors of $\mathbb{R}^{2}$ using unit vectors $(1,0)$ and $(0,1)$ (Figure 7 ).

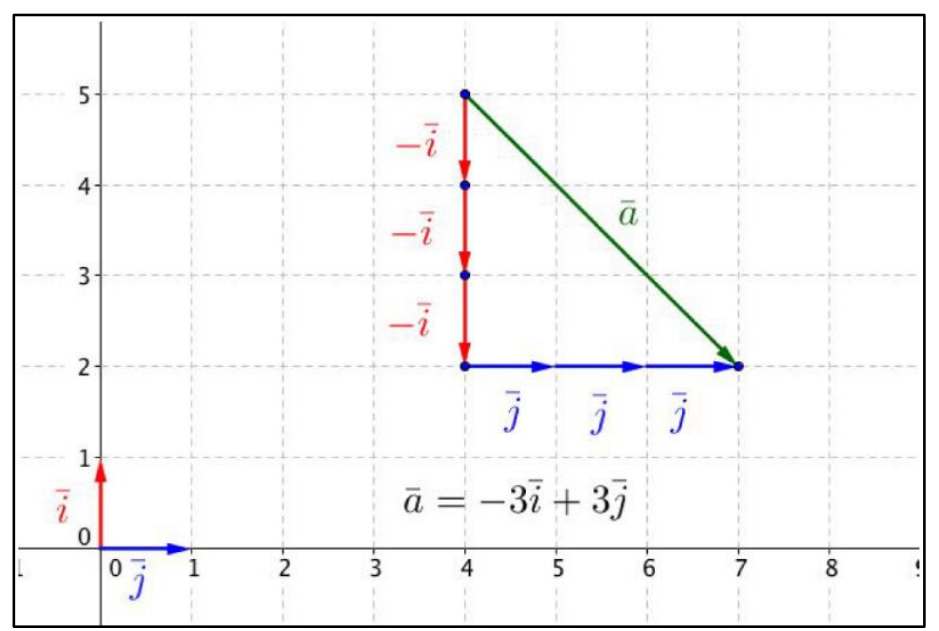

Figure 7. The representation of vector decomposition presented by Group 4.

In summary, Group 4 discussed representations related to vectors with versatility. However, very little attention was given to other areas of teacher knowledge. 


\subsection{Group 5}

Group 5 focussed heavily on the use of vectors in technology and everyday life (Table 9).

Table 9. The categorisation of the teacher knowledge produced by Group 5.

Common content knowledge Specialised content knowledge (33) (3)

\begin{tabular}{lll}
\hline \hline A formal definition (2), A & Applications (26), Linking a & Classification of concepts (1) \\
descriptive definition (1) & representation to an underlying idea or \\
& other representations (3), History of \\
& mathematics (2), An example (1), \\
& Mathematics and art (1)
\end{tabular}

The group's work was almost entirely composed of the applications of the mathematics related to vectors:

"Nowadays it [the Bézier curve] is used more extensively in industrial design [...]"

"With relation to these applications, the group also discussed some other areas of specialised content knowledge such as the history of mathematics:"

With relation to these applications, Group 5 also discussed some other areas of specialised content knowledge such as the history of mathematics:

"The Bézier curve was developed for designing car bodies by mathematician and engineer Pierre Bézier while working at Renault's car factory in the 1960s."

Common content knowledge received only a little attention in this group's work. However, some definitions related to the applications were presented (Figure 8). 


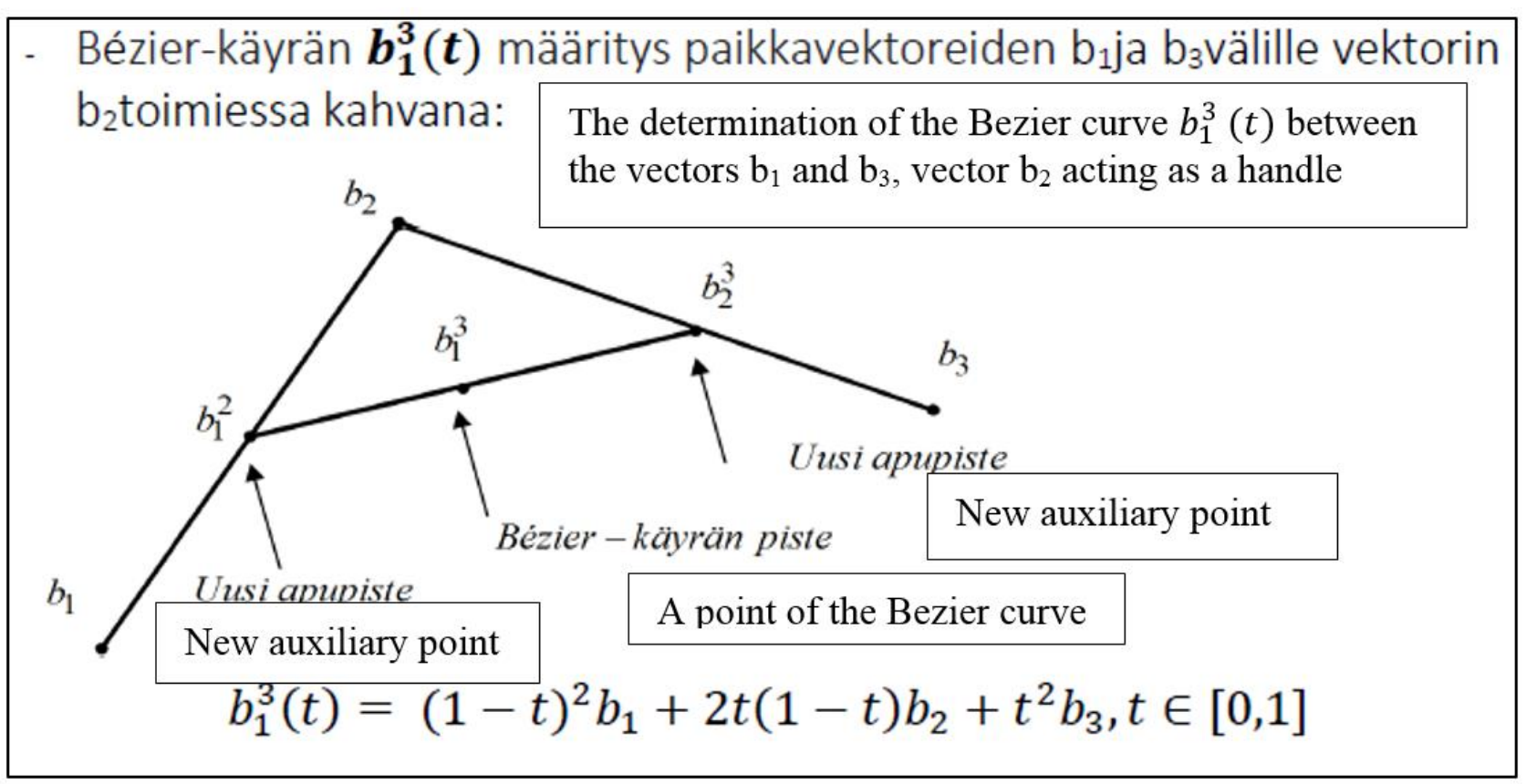

Figure 8. The definition of a Bézier curve presented by Group 5.

In summary, Group 5 presented many applications of vectors. Other areas of subject matter knowledge received only a little attention.

\subsection{Summary}

Overall, only Group 3 emphasised PCK whereas other groups focussed on SMK. Looking at the other four groups, the Group 1 focussed on common content knowledge and knowledge of content and curricula. However, Groups 2, 4 and 5 produced a considerable amount of specialised content knowledge (Table 10).

Table 10. The categorisation of the teacher knowledge produced by Groups 1, 2, 3, 4 and 5.

\begin{tabular}{l|llllll}
\hline & \multicolumn{2}{c}{ Subject matter knowledge } & \multicolumn{3}{c}{ Pedagogical content knowledge } \\
& CCK & SCK & HCK & KCS & KCT & KCC \\
\hline Group 1 & 8 & 2 & 1 & 0 & 0 & 4 \\
Group 2 & 3 & 6 & 2 & 0 & 0 & 0 \\
Group 3 & 0 & 2 & 0 & 11 & 1 & 0 \\
Group 4 & 6 & 25 & 0 & 2 & 0 & 1 \\
Group 5 & 3 & 33 & 1 & 0 & 0 & 0 \\
\hline
\end{tabular}

Groups 2, 4 and 5 produced qualitatively varying kinds of specialised content knowledge. Group 5 presented various applications of mathematics in everyday life and technology. However, these applications were rarely connected to common 
content knowledge or school mathematics contents. Group 4 focused on analysing characteristics of different representations of mathematical content. These representations were, however, rarely explicitly connected to other domains such as the structure of the mathematical theory. In contrast, Group 2 connected all the subdomains of SMK and, thereby, presented a wide overall view of one mathematical concept.

\section{Discussion}

In relation to the research question, the current study showed that open-ended PBL provoked the production mainly of specialised content knowledge. Compared to knowledge production seen in previous design cycles (Hannula, 2017; Hannula 2018b) a shift in emphasis from PCK to SMK seems evident. Thus, the proposed PBL approach seems to have the potential for enhancing SCK in mathematics teacher education. However, somewhat in conflict with the learning objectives, the category of HCK received only a little attention overall and only one group included HCK more notably in their work.

In terms of SCK, the current study adds to the prior research by describing secondary teachers' different approaches to the PBL task. The results of the current study show that open-ended problem-solving tasks may provoke the development of different subareas of SCK such as applications and representations. Thus, the design of the current study contrasts such designs proposed in prior research that support the development of narrower areas of SCK such as comparing solution strategies (e.g. Koellner et al., 2007). It may be that the development of teacher knowledge through PBL will consistently be narrower than that achieved with designs in which different components of teacher knowledge are more explicitly involved in the task (e.g. Silver et al., 2007). In terms of the development of instructional design, the challenge is how to avoid encouraging a fragmented view of knowledge and to advance the synthesis of the viewpoints of different student-teacher groups.

The results showed that this PBL task provoked relatively little consideration with respect to HCK. The existing research literature indicates that both pre-service and in-service teachers view advanced mathematical knowledge as being of only limited significance for teacher knowledge (Even, 2011; Hannula, 2018; Mosvold \& Fauskanger, 2014; Paolucci, 2015). In this study, it was found that a similar trend seems evident also in authentic learning situations. However, as the category of HCK 
is conceptually problematic, it might be that the pre-service teachers' views on the development of HCK in the task differ from the observations presented in this paper. Therefore, it would be valuable to conduct further research on pre-service teachers' conceptions of the development of HCK in these tasks. Additionally, the disregard of HCK might be caused by the difficulties in finding coherent connections between university mathematics and school mathematics (Chin, 2013; Hannula, 2018). Further studies could examine pre-service teachers' conceptions of vectors and linear algebra and find ways to support their HCK related to these topics. In the future, the cases could be designed more in line with the notion of HCK. Such cases should encourage utilising the knowledge of advanced mathematics in classroom situations such as using the knowledge of proof by contradiction to understand students' reasoning.

\section{Limitations and conclusion}

Some limitations of the current case study must be taken into account. Firstly, participants' knowledge or conceptions were not systematically tested by using standardised procedures such as pre- and postintervention by using questionnaires. Instead, the study provided information on an authentic learning situation. Secondly, case studies can only provide contextual information on the learning process. Therefore, the results of the current study cannot be generalised to other contexts. However, by means of a careful report, a repeatable procedure and a transferable design have been provided for further study and development. Lastly, this case study supports the view that the categories of the MKT model are conceptually problematic, as they seem to be contextual and not mutually exclusive. Consequently, further research is needed to clarify the components of mathematical knowledge for teaching.

Overall, as several groups produced diverse outputs categorised in specialised content knowledge, the findings of the current study suggest that the PBL approach enables pre-service secondary teachers to specialise their content knowledge for teaching purposes. Such knowledge is underrepresented in current maths teacher education (Koponen et al., 2016) and is associated with improved teaching practices (Hoover et al., 2016). Therefore, as the open-ended PBL approach provoked the development SCK, it seems to be one promising approach for developing maths teacher education. However, further research from different standpoints such as preservice teachers' views and knowledge is needed to evaluate the overall relevance and 
effect of such an approach. Additionally, as the amount of HCK produced in the task was relatively small, the findings of the current study support prior research literature (e.g. Wasserman, 2016; Wright et al., 2016) in the recommendation that new instructional practices and practice-based research are needed for the development of HCK.

\section{Acknowledgements}

This research was supported by the Jenny and Antti Wihuri Foundation under grant numbers 00160077 and 00170067 . I would like to express my gratitude to Juulia Lahdenperä who kindly helped me in the data analysis. I would also like to thank the members of our research group for commenting on an early version of the manuscript.

\section{References}

Ball, D. L., Thames, M. H., \& Phelps, G. (2008). Content knowledge for teaching: What makes it special? Journal of Teacher Education, 59(5), 389-407.

Biggs \& Tang (2011). Teaching for quality learning at university (4th ed.). Maidenhead: Open University Press.

Carrillo, J., Climent, N., Contreras, L., \& Muñoz-Catalán, M. (2013). Determining specialised knowledge for mathematics teaching. In B. Ubuz, C. Haser, \& M. A. Mariotti (Eds.), Proceedings of the Eighth Congress of the European Society for Research in Mathematics Education (pp. 2985-2994). Ankara, Turkey: Middle East Technical University and ERME.

Chin, K. E. (2013). Making sense of mathematics: Supportive and problematic conceptions with special reference to trigonometry. (PhD thesis) The University of Warwick.

Clark \& Lovric (2009). Understanding secondary-tertiary transition in mathematics. International Journal of Mathematical Education in Science and Technology, 4o(6), 755776.

Cohen, J. (1960). A coefficient of agreement for nominal scales. Educational and Psychological Measurement, 2O(1), 37-46.

DiSessa, A. A., \& Cobb, P. (2004). Ontological innovation and the role of theory in design experiments. The Journal of the Learning Sciences, 13(1), 77-103.

Edelson, D. C. (2002). Design research: What we learn when we engage in design. The Journal of the Learning Sciences, 11(1), 105-121.

Elo, S., \& Kyngäs, H. (2008). The qualitative content analysis process. Journal of Advanced Nursing, 62(1), 107-115.

Even, R. (2011). The relevance of advanced mathematics studies to expertise in secondary school mathematics teaching: Practitioners' views. Zdm Mathematics education, 43(6-7), 941950.

Goos, M., \& Bennison, A. (2018). Boundary crossing and brokering between disciplines in preservice mathematics teacher education. Mathematics Education Research Journal, 30(3), $255^{-275 .}$ 
Hannula, J. (2017). Subject matter knowledge and pedagogical content knowledge in the learning diaries of prospective mathematics teachers. In T. Dooley \& G. Gueudet (Eds.), Proceedings of the Tenth Congress of the European Society for Research in Mathematics Education (pp. 3312-3319). Dublin, Ireland: DCU Institute of Education \& ERME.

Hannula, J. (2018a). The gap between school mathematics and university mathematics: prospective mathematics teachers' conceptions and mathematical thinking. Nordic studies in mathematics education 23(1), 67-90.

Hannula, J. (2018b). Matematiikan aineenopettajaopiskelijoiden matemaattinen ja pedagoginen sisältötieto ongelmalähtöisessä oppimisessa. [Pre-service mathematics teachers' mathematical and pedagogical content knowledge in problem-based learning.] FMSERA Journal, 2(1), 134-144

Hmelo-Silver, C. E. (2004). Problem-based learning: What and how do students learn? Educational Psychology Review, 16(3), 235-266.

Hoover, M., Mosvold, R., Ball, D. L., \& Lai, Y. (2016). Making progress on mathematical knowledge for teaching. The Mathematics Enthusiast, 13(1/2), 3-34.

Jakobsen, A, Ribeiro, C. M., \& Mellone, M. (2014). Norwegian prospective teachers' MKT when interpreting pupils' productions on a fraction task. Nordic Studies in Mathematics Education, 19(3-4), 135-150.

Jakobsen, A., Thames, M. H., \& Ribeiro, C. M. (2013). Delineating issues related to horizon content knowledge for mathematics teaching. In B. Ubuz, C. Haser, \& M.A. Mariotti (Eds.), Proceedings of the Eighth Congress of the European Society for Research in Mathematics Education (pp. 1389-1398). Ankara, Turkey: Middle East Technical University and ERME.

Klein, F. (1932). Elementary mathematics from an advanced standpoint: Arithmetic, algebra, analysis. New York: Dover Publications. (Original work published in 1908).

Koellner, K., Jacobs, J., Borko, H., Schneider, C., Pittman, M. E., Eiteljorg, E . . Frykholm, J. (2007). The problem-solving cycle: A model to support the development of teachers' professional knowledge. Mathematical Thinking and Learning, 9(3), 273-303.

Koponen, M., Asikainen, M. A., Viholainen, A., \& Hirvonen, P. E. (2016). Teachers and their educators' views on contents and their development needs in mathematics teacher education. The Mathematics Enthusiast, 13(1/2), 149-170.

Landis, J. R., \& Koch, G. G. (1977). The measurement of observer agreement for categorical data. Biometrics, 33(1), 159-174.

Moreira, P. C., \& David, M. M. (2008). Academic mathematics and mathematical knowledge needed in school teaching practice: Some conflicting elements. Journal of Mathematics Teacher Education, 11(1), 23-40.

Mosvold, R., \& Fauskanger, J. (2014). Teachers' beliefs about mathematical horizon content knowledge. International Journal for Mathematics Teaching and Learning, 9(3), 311-327.

Paolucci, C. (2015). Changing perspectives: Examining the potential for advanced mathematical studies to influence pre-service teachers' beliefs about mathematics. Teaching and Teacher Education, 49, 97-107.

Papick, I. J. (2011). Strengthening the mathematical content knowledge of middle and secondary mathematics teachers. Notices of the AMS, 58(3), 389-392.

Schmidt, H. G. (1983). Problem-based learning: Rationale and description. Medical education, 17(1), 11-26.

Shulman, L. (1987). Knowledge and teaching: Foundations of the new reform. Harvard Educational Review, 57(1), 1-23.

Silver, E. A., Clark, L. M., Ghousseini, H. N., Charalambous, C. Y., \& Sealy, J. T. (2007). Where is the mathematics? Examining teachers' mathematical learning opportunities in practice- 
based professional learning tasks. Journal of Mathematics Teacher Education, 10(4-6), 261-277.

Sirotic, N., \& Zazkis, A. (2007). Irrational numbers: The gap between formal and intuitive knowledge. Educational Studies in Mathematics, 65(1), 49-76.

Tatto, M. T., Lerman, S., \& Novotna, J. (2009). Overview of teacher education systems around the world. In R. Even, \& D. L. Ball (Eds.), The professional education and development of teachers of mathematics: The 15th ICMI study (pp. 15-24). New York: Springer.

Toom, A., Kynäslahti, H., Krokfors, L., Jyrhämä, R., Byman, R., Stenberg, K. . . Kansanen, P. (2010). Experiences of a research-based approach to teacher education: Suggestions for future policies. European Journal of Education, 45(2), 331-344.

Tossavainen, T., Attorps, I., \& Väisänen, P. (2011). On mathematics students' understanding of the equation concept. Far East Journal of Mathematical Education, 6(2), 127-147.

Viholainen, A. (2008). Finnish mathematics teacher student's informal and formal arguing skills in the case of derivative. Nordic Studies in Mathematics Education, 13(2), 71-92.

Wasserman, N. H. (2016). Abstract algebra for algebra teaching: Influencing school mathematics instruction. Canadian Journal of Science, Mathematics and Technology Education, 16(1), $28-47$.

Wasserman, N., Weber, K., Villanueva, M., \& Mejia-Ramos, J. P. (2018). Mathematics teachers' views about the limited utility of real analysis: A transport model hypothesis. The Journal of Mathematical Behavior, 50, 74-89.

Wright, M., Murray, E., \& Basu, D. (2016). Impact of abstract algebra knowledge on the teaching and learning of secondary mathematics. In T. Fukawa-Connelly, N. Engelke Infante, M. Wawro \& S. Brown (Eds.), Proceedings of 19th Annual Conference on Research in Undergraduate Mathematics Education (pp. 481-495). Pittsburgh, Pennsylvania.

Yin, R. K. (1994). Case study research: Design and methods (2nd ed.). Newbury Park, CA: SAGE Publications.

Zazkis, R., \& Leikin, R. (2010). Advanced mathematical knowledge in teaching practice: Perceptions of secondary mathematics teachers. Mathematical Thinking and Learning, 12(4), 263-281. 


\section{Appendix I: The case of the PBL project}

\section{The original case written in Finnish:}

Antti Aineenopettaja pääsi matematiikan ja tilastotieteen laitokselle opiskelemaan matematiikan aineenopettajaksi, mikä oli hänelle mieluisa vaihtoehto, sillä koki oppineensa matematiikkaa koulussa hyvin ahkeran opiskelunsa myötä (matematiikka oli hänen vahvin kouluaineensa, yleensä 9 tai 10). Lisäksi opetustyö tuntui hänestä hyvältä uravalinnalta; hän piti jo koulussa siitä, kun sai auttaa muita oppilaita tehtävissä.

Yliopistossa yhtenä ensimmäisistä kursseistaan hän opiskeli kurssin "Lineaarialgebra ja matriisilaskenta”. Kurssilla oli lähtötasotesti, joka käsitteli vektoreita. Näin ollen Antti päätteli, että kurssi tulisi liittymään jollakin tavalla lukiossa opetettuihin vektoreihin ja hän kertasikin nopeasti pääkohdat lukion vektorikurssista.

Antti käsitti vektorit lukion pohjalta nuolina eli olioina, joilla on suunta ja suuruus. Hyvänä esimerkkinä käytännön esimerkkinä hän muisti joen virtauksen, joka vie venettä tiettyyn suuntaan tietyllä voimalla. Tällaisia kutsuttiin vektorisuureiksi, joita oli mukava laskea. Erityisesti kun niitä tarkasteltiin koordinaatistossa, jossa vektori esitettiin esimerkiksi muodossa $3 \mathrm{i}+4 \mathrm{j}$. Vektoreiden yhteenlaskun ja vakiolla kertomisen Antti ymmärsi hyvin. Yksi oudompi laskutoimitus oli pistetulo, joka määriteltiin kaavalla $\mathbf{a} \cdot \mathbf{b}=|\mathbf{a}| \cdot|\mathbf{b}| \cdot \cos \alpha$, missä $\alpha$ on vektoreiden $\mathbf{a}$ ja $\mathbf{b}$ välinen kulma. Pistetulosta Antti oppi, että kahden vektorin pistetulo on nolla silloin, kun vektorit ovat toisiaan vasten kohtisuorassa.

Lineaarialgebran kurssilla käsiteltiin myös vektoreita, mutta nyt vektorit esitettiin järjestettynä parina, esim. $(3,6)$ tai jonona, esim. $(2,-3,4,1,-3)$. Kahden vektorin pistetulo määriteltiin kaavalla, $\mathbf{a} \cdot \mathbf{b}=\mathrm{a}_{1} \cdot \mathrm{b}_{1}+\mathrm{a}_{2} \cdot \mathrm{b}_{2}+\ldots+\mathrm{a}_{\mathrm{n}} \cdot \mathrm{b}_{\mathrm{n}}$, eli laskemalla vektoreiden komponenttien tulot ja laskemalla ne yhteen. Vektorit olivat Antin mielestä tällä kurssilla jotenkin erilaisia kuin lukiossa; lukiossa esimerkiksi pisteen $(3,6)$ paikkavektoriksi sanottiin vektoria $3 i+6 j$, nyt itse piste $(3,6)$ oli vektori. Pian edettiin matriiseihin, jotka tuntuivat taas Antista harppaukselta johonkin uuteen. Lineaarialgebran kurssi meni lopulta Antilla hyvin ja hän koki oppineensa asioita, joskin kokonaisuus jäi osittain hajanaiseksi.

Myöhemmin opinnoissaan Antti törmäsi myös siihen, miten vektori voidaan määritellä tarkasti myös geometrisesti keskenään yhtenevien suuntajanojen 
ekvivalenssiluokkana. Nyt Antilla oli useita eri tapoja lähestyä vektoreita ja kokonaisuus alkoi hahmottua.

Opetusharjoittelussa Antti pääsi opettamaan lukion vektorikurssia. Hän kävi läpi oppikirjaa, jossa aluksi vektoreita esitettiin yleisesti geometrisina otuksina ja fysikaalisten sovellusten kautta. Pian siirryttiin laskemaan vektoreilla koordinaatistossa. Antin oli määrä pitää oppitunteja liittyen mm. vektorin käsitteeseen, vektoreiden laskusääntöihin, vektoreiden esittämiseen kantavektoreiden avulla ja pistetuloon.

Antti mietti, että hänellä on kokonaisuus hallussa kohtuullisen hyvin, mutta vieläkin jotkut asiat olivat vähän epäselviä. Hän mietti mm., miten "geometriset vektorit" ja "koordinaatistovektorit" liittyvät toisiinsa, mikä pistetulo oikeastaan on, käytetäänkö lineaarialgebraa jossakin muussakin kuin fysiikassa ja mihin matematiikan aloihin lineaarialgebra oikeastaan liittyy. Hän tiesi, että hän selviäisi opetusharjoittelusta, vaikkei osaisikaan vastata tarkasti edellisiin kysymyksiin, mutta olo tuntui silti hieman epävarmalta: kokonaisuuden hahmottamisessa oli vielä aukkoja!

\section{An English translation of the case:}

Antti got a right to study as mathematics teacher at a Department of Mathematics and Statistics. This was a pleasant choice for him, as he thought that he had learned maths well in school due to his studious attitude. (Mathematics was his strongest subject, usually the grade was 9 or 10 out of 10.) Additionally, teacher's work seemed as a good career choice for him. He enjoyed helping other students already in school.

One of his first courses at the university was "Liner algebra and matrices". The course had a placement test regarding vectors. Therefore, Antti concluded that the course had something to do with vectors learned at secondary school. He revised the main topics of the secondary school vector course.

From his secondary school experiences, Antti perceived vectors as arrows i.e. objects that have a direction and a magnitude. As a good example to him, was the flow of river that takes the boat into a certain direction in a certain force. These were called as vector magnitudes and Antti enjoyed calculating these. Especially, when the vectors were examined in a set of coordinates and they were expressed for instance in form $3 i+4 j$. Antti understood well the addition and multiplication of vectors. One of the more complicated operations was the dot product that was defined with the 
formula $\mathbf{a} \cdot \mathbf{b}=|\mathbf{a}| \cdot|\mathbf{b}| \cdot \cos \alpha$, where $\alpha$ is the angle between the vectors $\mathbf{a}$ and $\mathbf{b}$. Antti learned that the dot product of two vectors is zero if the vectors are perpendicular to each other.

Vectors were discussed also in the linear algebra course, but now the vectors were expressed as ordered pairs such as $(3,6)$ or sequences such as $(2,-3,4,1,-3)$. The dot product was defined with a formula $\mathbf{a} \cdot \mathbf{b}=a_{1} \cdot b_{1}+a_{2} \cdot b_{2}+\ldots+a_{n} \cdot b_{n}$, that is, calculating the multiplications of the components of the vectors and adding them up. In this course, Antti thought that vectors were different from the ones in secondary school. In secondary school, the place vector of the point $(3,6)$ was $3 i+6 j$ and now the point itself was a vector. Soon the course proceeded to matrices and to Antti this was again something different. In the end, the course went well and Antti thought that he had learned a great deal, even though the big picture remained a bit fuzzy.

Later in his studies, Antti run into a geometric definition of vectors through equivalence classes of directed line segments. Now Antti had several approaches to vectors and the big picture started to take shape.

During his practical training, Antti has to teach the vector course of secondary school. He went through the textbook that started by introducing the vectors as geometric object and through physics applications. Soon the textbook proceeded to calculations in a set of coordinates. Antti was supposed to give lessons regarding the vector concept, the operations of vectors, the expression of vectors through basis vectors and dot product.

Antti thought that he handled these topics quite well, even though some things were still unclear to him. He wondered things such as "How are 'geometric vectors' related to 'coordinative vectors'?”, "What is dot product, really?", "Is linear algebra applied in any other discipline than physics" and "Which areas of mathematics is linear algebra related to?”. He knew that he would survive his practical training without having the answers but he felt a bit uncertain: the big picture is was not yet without gaps! 


\section{Appendix II: The working schedule of the groups}

\begin{tabular}{|l|l|l|l|}
\hline Week & The objective & $\begin{array}{l}\text { The steps of Schmidt's } \\
\text { model }\end{array}$ & $\begin{array}{l}\text { Instruction / individual } \\
\text { work }\end{array}$ \\
\hline Week 1 & $\begin{array}{l}\text { Analysing the case and } \\
\text { formulating learning } \\
\text { objectives }\end{array}$ & $1-5$ & $\begin{array}{l}2 \times 45 \text { minutes of } \\
\text { instruction }\end{array}$ \\
\hline Week 2 & $\begin{array}{l}\text { Collecting additional } \\
\text { information outside the } \\
\text { group }\end{array}$ & 6 & Individual work \\
\hline Week 3 & $\begin{array}{l}\text { Making the synthesis } \\
\text { and presentation of the } \\
\text { work }\end{array}$ & 7 & $\begin{array}{l}\text { Individual work }+2 \times 45 \\
\text { minutes of instruction }\end{array}$ \\
\hline
\end{tabular}

